Näkökulma

Prologi - puheviestinnän vuosikirja 2019

\title{
Poliittisen standup-komedian sukupuolittuneisuus Valkoisen talon kirjeenvaihtajien illallisilla
}

\section{Outi Hakola}

FT, Akatemiatutkija

Kulttuurien tutkimuksen osasto

Helsingin yliopisto

outi.j.hakola@helsinki.fi

Standup-komedia on levinnyt komediaklubeilta Netflixin kaltaisten suoratoistopalveluiden lisäksi areenoille ja suoriin TV-lähetyksiin. Jälkimmäisestä tunnetuin esimerkki on Yhdysvalloissa vuosittain järjestettävä gaala, Valkoisen talon kirjeenvaihtajien illallinen. Gaala juhlii lehdistön- ja sananvapautta, ja palkitsee poliittisen journalismin toimijoita. Palkitseminen tapahtuu kuitenkin sukupuolittuneessa kontekstissa. Vaikka illallisgaala on suunnattu erityisesti yhdysvaltaisille poliittisille toimijoille, mukaan lukien presidentti ja hänen hallintonsa, keskeiset puoluepoliittiset toimijat ja politiikan toimittajat, tilaisuudesta on kasvanut julkisesti seurattu tapahtuma. ${ }^{1}$ Koska tilaisuudesta on muodostunut poliittisen komedian näytösperinne, illalliset mahdollistavat kulttuuristen asenteiden siirtymien tarkastelun poliittisessa komediassa.

Nykymuotoisen standup-komedian perinteet ovat kehittyneet Yhdysvalloissa, jonka komediakenttä toimii edelleen alan trendien synnyttäjänä ja levittäjänä. Tämä tekee yhdysvaltalaisesta komediasta merkittävän myös suomalaisessa kontekstissa, eikä vähiten siksi, että myös suomalaiset koomikot, tunnetuimpana Ismo Leikola, ovat tehneet kansainvälistä uraa nimenomaan Yhdysvalloissa.

Standupia, ja erityisesti politiikkaan kohdistuvaa komediaa, on perinteisesti pidetty miehisenä esiintymisen lajina. Miehet ovat hallinneet komedialavoja määrällisesti, ja ainakin osa ylei- 
söstä on olettanut poliittisen standupin hyökkäävän tyylin soveltuvan paremmin miesesiintyjille (Sherine, 2016). Käsitys on vanhentunut naiskoomikkojen noustessa esiintymislavoille. Naiskoomikot ovat saaneet lisää näkyvyyttä 2000-luvulla eivätkä he ole kaihtaneet aggressiivista esiintymistä. Muun muassa Michelle Wolf, Samantha Bee, Chelsea Handler ja Ali Wong ovat kyseenalaistaneet suorasukaisten, jopa vulgaarien esiintymistensä avulla, mistä aiheista ja millä tyylillä naiset voivat tehdä komiikkaa. Heidän esiintymisensä kritisoi kulttuurisia oletuksia, joiden mukaan komedialliset esiintymistyylit sitoutuisivat koomikon sukupuoleen.

Tässä näkökulma-artikkelissa nostan esiin sukupuolijännitteen, joka vuonna 2018 konkretisoitui, kun Michelle Wolfin standup-esitys aiheutti julkisen kohun. Väittelyn kohteeksi nousi Wolfin suorasukaisten ja aggressiivisten vitsien tyyli suhteessa poliittiseen puolueellisuuteen ja naiseuteen (Hakola, 2019). Wolfin aiheuttama kohu johti myös gaalan komediaperinteen katkeamiseen ja vuonna 2019 tilaisuudessa esiintyi historioitsija Ron Chernow. ${ }^{2}$

Standupin yleistyminen on kirvoittanut keskustelua sukupuolenjälkeisyydestä. Yhtäältä se liittyy naiskoomikoiden esille nousuun ja toisaalta keskusteluun post-yhteiskunnasta, jossa esimerkiksi rodulla ja sukupuolella ei olisi enää merkittävää vaikutusta yksilöiden yhteiskunnalliseen asemaan. Koomikkojen esiintymistä selitetään heidän tekemillään tyyli- ja sisältövalinnoilla, ei heidän sukupuolellaan. Millaista sukupuolenjälkeinen (post-gender) komedia voisi olla ja millaisena potentiaali näyttäytyy tämän hetken yhdysvaltalaisella komediakentällä?

\section{Standup ja poliittisen komedian sukupuolittuneisuus}

Poliittisessa standup-komediassa korostuu vuorovaikutuksellisuus, sillä standup tapahtuu aina tietyssä hetkessä, paikassa ja yleisön edessä. Esiintyjän ja yleisön vuorovaikutussuhde edellyttää molempien osallistumista ideaalisesti siten, että yleisöstä tulee yhtä lailla tilanteen rakentaja ja esiintyjä (Brodie, 2008; Double, 2015). Poliittisen komedian kapinalliseen ja transformatiiviseen huumoriin sisältyy oletus, että yleisö tunnistaa aiheen lisäksi siihen liittyvän valta-asetelmien haastamisen ja poliittisen diskurssin absurdin luonteen. Jaettu kokemus hierarkioiden haastamisesta voi synnyttää yhteisöllistä naurua, mikäli koomikko onnistuu ottamaan yleisön mukaan huumorin rakentamiseen. Lindforsin (2019) mukaan standupin vuorovaikutuksellisuudessa on kolme keskeistä tekijää: koomikon julkinen itsensä esittäminen sanallisen ja sanattoman viestinnän avulla, koomikon kyky kannustaa yleisön osallistuvuutta ja luoda yhteisöllinen kokemus, sekä viestintä tavalla, joka sekä ohjaa yleisön huomiota että alistaa onnistumisensa yleisön arvioitavaksi.

Vaikka standupin perinne kumpuaa lavaesiintymisestä, medioituneessa kulttuurissa jossa esityksiä taltioidaan ja lähetetään kotiyleisöille, vuorovaikutus saa erityisiä piirteitä. Kirjeenvaihtajien illallisilla komedia toimii palautteena poliittisille toimijoille, jossa paikalla oleva yleisö edustaa poliittisen satiirin kohdetta. Kotiyleisö

${ }^{1}$ Julkisen palvelun televisioyhtiö C-SPAN on televisioinut gaalan vuodesta 1993 saakka.

${ }^{2}$ Ainoastaan kahdesti aiemmin on poikettu komediaperinteestä vuoden 1983 jälkeen. Vuonna 1999 pääesiintyjänä oli laulaja Aretha Franklin, mutta tuolloinkin mukana oli Brian Williamsin esittämä sketsi. Laulaja Ray Charles esiintyi gaalassa vuonna 2003, sillä juuri alkaneen Irakin miehityksen takia presidentti George W. Bush piti koomikon kutsumista epäasiallisena. 
ei vaikuta vuorovaikutustilanteen syntymiseen, vaan heille tunnelma välittyy paitsi koomikon myös paikalla olevan yleisön kautta (Brock, 2015; Brodie, 2008). Paikalla olevan yleisön reaktiot - nauru, taputus, hiljaisuus ja kameran kuvaamat ilmeet ja eleet - antavat vihjeitä yhteisöllisestä naurusta tai sen epäonnistumisesta. Koska kirjeenvaihtajien illallisilla paikalla oleva yleisö on myös komedian kohteena, kotiyleisöllä on mahdollisuus nauttia yhteisöllisestä naurusta suhteessa poliittisen satiirin osuvuuteen.

Niinpä huomio kiinnittyy myös roastaamisen (roasting) kohteena olevien kykyyn ottaa palaute vastaan. Roastaamisessa tunnettua henkilöä pilkataan julkisesti, joskin usein hyväntahtoisesti komediallisessa esiintymisessä siten että kohde on tyypillisesti läsnä tilaisuudessa (Ritchie, 2014; Rossing, 2017). Roastaaminen antaa kohteelle mahdollisuuden osoittaa, pystyykö hän nauramaan itselleen. Erityisesti poliittisessa komediassa kykyä ottaa vastaan kritiikkiä arvostetaan ja onnistuessaan se on jopa kasvattanut kyseisen poliitikon suosiota, sillä tällöin hän on osoittanut kykenevänsä vuorovaikutukselliseen suhteeseen sekä yleisön että median kanssa (Cramer Brownell, 2016; Higgie, 2017). Roastaamisessa yleisö kohdistaa arvioivan katseensa paitsi koomikkoon myös vitsien kohteena olevan tahon toimintaan ja reaktioihin. Kahden eri yleisön olemassaolo on osoitus siitä, että vitsit, jotka aiheuttavat paheksuntaa Washingtonissa, voivat olla hauskoja televisioyleisölle.

Vuodesta 1921 järjestetyille Valkoisen talon kirjeenvaihtajien illallisille sallittiin naisjournalistien osallistua vasta vuonna 1962. Vuodesta 1983 alkaen tilaisuuteen on tyypillisesti kutsuttu koomikko, mutta myös esiintyjissä naiset ovat muodostaneet vähemmistön. Vuosien varrella illallisilla on esiintynyt 22 mieskoomikkoa, joista osa on esiintynyt tilaisuudessa useamman kerran, Jay Leno jopa neljästi. Naisia esiintyjis- tä on koko aikana ollut viisi. Asetelma korostaa tilaisuuden sukupuolittuneisuutta, ja voi vahvistaa kulttuurista mielikuvaa, jossa poliittinen komedia olisi erityisesti miehille sopiva laji.

Feministiset näkökulmat ovat kuitenkin haastaneet käsityksiä miesten erityisestä soveltuvuudesta poliittisiin keskusteluihin, koska naisten pitkäaikainen tavoite muuttaa ja paljastaa yhteiskunnallisia ja poliittisia valtasuhteita ja -rakenteita vastaa poliittisen komedian tavoitteita (Colletta, 2014; Mizejewski, 2014). Komediatutkimus nykyään vastustaakin jakoa miesten ja naisten komediamuotoihin. Tutkijat ovat nähneet tärkeämpänä tutkia eri koomikoiden välisiä eroja ja samankaltaisuuksia kuin pyrkiä selittämään niitä yksinkertaistavasti ja yleistävästi sukupuolella (Gilbert, 2004; Shouse \& Oppliger, 2012). Kehitys on johtanut sukupuolenjälkeisyyden pohtimiseen.

Englanninkielisen keskustelun post-gender käsite on haastava suomennettava, sillä se voi tarkoittaa niin sukupuolettomuutta, sukupuolikategorioita ylittävää tai sukupuolenjälkeisyyttä. Samalla kääntäminen mahdollistaa pohdinnan, mihin käsite voi venyä. Käsite kuuluu osaksi kriittisen teorian post-ajattelua. Josephin (2009) mukaan post-teorioiden tavoitteena on ollut siirtää huomio tyypillisten analyysikategorioiden tuolle puolelle. Tästä huolimatta etuliitteen käyttö ei poista jälkimmäisen sanan merkityksiä, vaan voi jopa vahvistaa niitä ja tehdä keskustelun kohteena olevan asian, kuten sukupuolen, entistä näkyvämmäksi toiminnallisemmaksi käsitteeksi. (Joseph, 2009.)

Osa tutkijoista käyttää kuitenkin post-liitettä sukupuolikategorioiden (sex/gender) poistamiseen, jolloin sukupuoli ei enää toimisi tunnistamisen tai merkityksellistämisen välineenä. Esimerkiksi Nicholasille (2014) sukupuolenjälkeisyys on kuviteltu tulevaisuus, jossa essen- 
tialistiset ja toisilleen vastakkaiset sukupuolijaot ja -hierarkiat eivät määrittele yksilöiden kokemuksia, vaan on toisenlaisia tapoja olla olemassa, luoda suhteita muihin ja jakaa normeja. Mahdollisuuksia sukupuolettomaan olemiseen on etsitty ei-binaarisista sukupuoli-identiteeteistä, queer-kokemuksista, androgyyneistä ja posthumanismin muodoista, kuten kyborgeista (esim. Butler, 1990; Deutscher, 1997; Haraway, 1991; Nicholas, 2014). Samoin sukupuolettomassa komediassa sukupuoli ei olisi enää millään tavoin merkittävä elementti.

Pelkästään se, että Michelle Wolfin komediamonologi synnytti julkista keskustelua koomikon sukupuolesta osoittaa, ettei sukupuoleton komedia ole lähellä toteutumista. Sukupuolettomuuden ideaalia onkin kritisoitu sen tavoitteesta poistaa tunnistettavissa olevat, sosiaalisesti ja yhteiskunnallisesti merkittävät sukupuolijaottelut, joista keskustelematta jättäminen voisi hankaloittaa sosiaalisten jännitteiden tunnistamista (Deutscher, 1997; Joseph, 2009). Komediatutkimuksessa sukupuolenjälkeisyyttä kannattaakin lähestyä kriittisenä käsitteenä, joka tarkastelee, miten nykyisiä sukupuoleen liittyviä kulttuurisia oletuksia voitaisiin purkaa ja ylittää. Sukupuolenjälkeisyys voi tavoitella niiden hierarkioiden purkamista, joissa sukupuoli määrittelee valtavirtaan tai marginaaliin asettumista tai sitä, millaista komediaa keneltäkin oletetaan. Tässä tulkinnassa "post" ei hävitä sukupuolta näkyvistä, vaan kiinnittää siihen eri tavalla huomiota.

\section{Esiintyjien sukupuolella on merkitystä komedialle}

Lindforsin (2019) mukaan esiintyjän (lava-) persoona on merkittävä vuorovaikutuksen synnyttäjä standup-komediassa, sillä ihmiset arvioivat paitsi vitsien sisältöä, myös esiintyjän läsnäoloa, yksilöllisyyttä ja esitystyyliä.
Lavapersoonaan vaikuttavat myös kulttuuriset piirteet ja odotukset, jotka kiinnittyvät muun muassa sukupuolen, seksuaalisuuden, rodun ja etnisyyden kysymyksiin. Nämä piirteet ovat näkyvissä myös Kirjeenvaihtajien illallisilla.

Kirjeenvaihtajien illallisilla naisia on ollut esiintyjinä niin harvoin, että heidän kutsuminen näyttäytyy poliittisena valintana. Ensimmäinen gaalan naiskoomikko, Paula Poundstone, joka esiintyi tilaisuudessa vuonna 1992, pettyi, kun media keskittyi hänen esiintymisasuunsa (valkoinen smokki), eikä siihen, mitä hän sanoi. Poundstone tulkitsi tämän sukupuolittuneeksi kohteluksi, vaikka hän itse ei näe monologiaan osana sukupuolipolitiikkaa (Kahn, 2015). Tämänkaltainen julkinen kommentointi asettaa miehet edustamaan valtavirtaa ja naiset sukupuoltaan, mikä tekee esiintyjän sukupuolesta osan poliittisen komedian vuorovaikutuksellisuutta.

Gaalan identiteettipolitiikassa koomikon kriittinen etäisyys korostuu. Lähes kaikki tilaisuudessa esiintyneet koomikot erottautuivat Washingtonin poliittisista piireistä. Heille Washington näyttäytyi eliittinä tai sisäpiirinä, joka on irrallaan kansasta. Sen sijaan koomikot korostivat edustavansa joko kansaa ja/tai Hollywoodia, joiden molempien tehtävä on kriittisesti arvioida poliittisia toimijoita. Esimerkiksi Al Franken (1994) korosti, että Hollywoodista löytyy rohkeutta kertoa totuus, Conan O'Brien (1995), Jon Stewart (1997) ja Jimmy Kimmel (2012) korostivat ulkopuolisuuttaan nimetessään itsensä (viihdeteollisuuden) turisteiksi pääkaupungissa, ja Drew Carey (2002) ja Cedric the Entertainer (2005) välittivät päättäjille viestejä "kansalta". Esityksissään koomikot asettivat itsensä samalle viivalle kotiyleisön, ei niinkään paikan päällä olevan yleisön kanssa. 
Myös koomikoiden henkilökohtaiset piirteet vaikuttivat vuorovaikutukseen. Vuonna 1993 tilaisuuteen oli kutsuttu naiskoomikko Elayne Boosler, joka aloitti identifioimalla itsensä juutalaiseen ja työväenluokkaiseen taustaan. Sen sijaan hän ei nimennyt omaa naiseuttaan, mutta puhui naisista yhteisöllisessä "me"-muodossa vitsien yhteydessä. Booslerin jälkeen tilaisuudessa kuultiin 13 mieskoomikkojen esitystä vuosina 1994-2008, joissa kaikissa painottui eri tavoin (valkoisen) miehen näkökulma. Samalla tavoin kuin Boosler, Al Franken (1994) kohdisti osan kriittisistä seksuaalisävytteisistä vitseistään miehille ("are you with me, fellas?"), ja vuonna 1996 hän käsitteli feminismiä miehisestä, joskin feminismiä puolustavasta näkökulmasta todetessaan, etteivät feministit oikeasti tarkoita pilata muiden iloa. Franken kritisoi sukupuoliin liittyviä stereotypioita, mutta samalla kohdisti kritiikin muille miehille. Molempien kohdalla me/he-jaottelu synnyttää vuorovaikutustilanteeseen jännitettä, joka toimii myös poliittisen palautteen antamisen keinona.

Sen sijaan Jay Lenolle (2000; 2004), Drew Careylle (2002) ja Rich Littlelle (2007) heidän sukupuolensa näyttäytyi pitkälti näkymättömänä kategoriana, joka oletetusti ei vaikuttaisi heidän objektiivisen tarkkailevaan näkökulmaan. Joillekin toisille sukupuoli-identiteetti toimi esiintymistyylin ja sanoman vahvistajana. Conan O'Brien (1995) halvensi omaa maskuliinisuuttaan ("olen vielä neitsyt"), Jon Stewart (1997) kertoi etsineensä äidiltään vinkkejä tilaisuuteen, Ray Romano (1998) korosti rooliaan perheenisänä ja Darrell Hammond (2001) totesi isänsä ajatelleen häntä outona / queerinä poikana. Kaikissa näissä tapauksissa hyödynnetään erimuotoisia tai feminiiniseksi koettuja maskuliinisuuksia vitsien loukkaavuuden piilottamiseen ja pehmentämiseen. Päinvastaista strategiaa hyödyntäen Stephen Colbert (2006) rakensi poliittisen satiirinsa perinteiselle ide- aalille maskuliinisuudesta. Colbertin monologi pohjasi konservatiivisen, hyvää tarkoittavan, mutta huonosti informoidun miehen fiktiiviseen hahmoon, joka määrittelee monologissa itsensä "yksinkertaiseksi mieheksi, jolla on yksinkertainen mieli". Ironia, joka esitettiin valkoisen, konservatiivisen mieshahmon kautta, oli äärimmäisen purevaa ja aggressiivista.

2000-luvun puolella koomikkovalinnat alkoivat monipuolistua, ja samalla identiteettipolitiikasta tuli avoimempaa. Cedric the Entertainerille (2005) sukupuoli näyttäytyy pitkälti näkymättömänä kysymyksenä, mutta sen sijaan hän lähestyi tilannetta rodullistetusta mustan miehen näkökulmasta ja kohdisti kritiikkinsä valkoisiin ihmisiin. Irlantilaistaustainen Craig Ferguson (2008) puolestaan huomioi maahanmuuttajataustansa ja piti tuhmaa/rivoa (naughty), joskin kohtuullisen kilttiä kommentointityyliään, osana ulkopuolisuuttaan. Barack Obaman kauden alussa, kun keskustelu post-yhteiskunnasta kiihtyi Yhdysvalloissa, lavalle astui seuraava naiskoomikko, Wanda Sykes (2009), joka samalla tavalla kohdisti yleisön huomion omaan rodullistettuun taustaansa. Hänkään ei rakentanut esitystään sukupuolen varaan, vaan huomioi olevansa mustana koomikkona ylpeä siitä, että Yhdysvallat valitsi itselleen mustan presidentin.

Tästä eteenpäin esiintymispersoonan tunnistaminen osaksi monologia yleistyi. Jay Leno (2010) pysytteli vielä yleistettävyyden strategiassa, mutta vaikka häntä seuraavat Seth Meyers (2011), Jimmy Kimmel (2012) ja Conan O’Brien (2013) eivät korostaneet esityksissään vahvasti omaa mieheyttään tai etnisyyttään, he rakensivat vitsit minä-näkökulman muotoon. Joel McHale (2014) kohdisti kriittisen katseen yhteiskunnan ja politiikan sukupuolittamisen ja rodullistamisen käytänteisiin. Hän oli ainoa mieskoomikko, joka nosti myös itse illallisten 
sukupuolittuneisuuden esille pohtimalla, miten gaala edustaa kaikkien makkarajuhlien lähdettä ("\#total sausage fest").

Seuraavana vuonna tilaisuuteen kutsuttiinkin naiskoomikko Cecily Strong (2015). Hän aloitti monologin itsemäärittelyllä todetessaan olevansa se etnisesti monitulkintainen tyttö jokaisesta yliopistomainoksesta. Hän totesi myös ironisesti olevansa ensimmäinen heteronainen tilaisuudessa 20 vuoteen, joten hänen esiintymistään voidaan pitää voittona kaikille heteroille. Strongia seuranneet Larry Wilmore (2016) ja Hasan Minhaj (2017) samalla tavalla sisällyttivät itsemäärittelyn esityksen alkupuolelle. Wilmore totesi olevansa musta mies, joka kritisoi valkoisia rikkaita ja valtaapitäviä ihmisiä tästä näkökulmasta. Minhaj puolestaan samoin kohdisti kritiikkinsä valkoisuuteen muslimimaahanmuuttajan näkökulmasta.

Viimeisin koomikko, Michelle Wolf (2018), puolestaan astui lavalle naisena. Hän avasi puheensa toteamalla, että on vuosi 2018, hän on nainen ja häntä ei voi hiljentää. Wolf myös hyödynsi sukupuolista me/he-asetelmaa, ja hän teki naisista pääyleisönsä ja itsestään heidän edustajansa puhuttelemalla heitä "naiset, te tiedätte, mitä tämä tarkoittaa”. Puhutteluvalinnoilla Wolf otti paitsi lavan, myös julkisen keskustelun retorisen vallan naisille. Kirjeenvaihtajien illallisten koomikkojen identiteettipolitiikka ei siten korostakaan vain heidän etäisyyttään valtaapitävistä, vaan myös sitä, keitä he kokevat edustavansa.

Kirjeenvaihtajien illallisten komediaesityksistä huomataan, että vuosien varrella itsereflektio - kohdistuu se sukupuoleen, etnisyyteen, rodullisuuteen tai muihin elementteihin - on kasvanut, ei vähentynyt. Kyse ei ole naisiin kohdistuvasta ilmiöstä, jossa naiseudesta rakentuu osa komediallista vuorovaikutusta, vaan etenkin mieskoomikoiden tietoisuus omasta sukupuolisuudestaan ja sen vaikutuksesta on kasvanut. (Valkoinen) mieheys ei enää näyttäydy ikään kuin näkymättömänä asemana, josta yhteiskuntaa voi objektiivisesti tarkastella. Kehitys vahvistaa myös sen, ettei poliittinen komedia ole liikkumassa sukupuolettomuuden suuntaan. Pikemminkin sukupuolesta ollaan tultu entistä tietoisemmaksi, mikä puolestaan mahdollistaa eri sukupuoliin (ei vain mies/nainen-jaotteluun) liittyvien arvojen, asenteiden ja kulttuuristen asemointien näkyväksi tekemistä.

\section{Komedian sisältö ja tyyli on henkilöön menevää sukupuolesta riippumatta}

Koska sukupuoli on edelleen merkittävä sosiaalinen ja kulttuurinen kategoria, myös komedia käsittelee sukupuolijännitteitä. Samoin sukupuolenjälkeinen komedia ei tarkoita, etteikö sukupuolista ja sukupuolittuneisuudesta tulisi tehdä huumoria. Samalla tavalla kuin koomikot ovat kasvavasti hyödyntäneet sukupuoltaan osana esitysten itsereflektiota ja yleisön puhuttelua, myös sukupuoleen liittyvät vitsit ovat yleistyneet vuosien varrella. Kirjeenvaihtajien illallisilla on omat perinteiset vitsien aihealueet - tilaisuuden luonne, median ja politiikan jakautuminen eri leireihin ja ajankohtaiset poliittiset ilmiöt, joista kaikista on löydetty myös sukupuoleen liittyviä teemoja. Sekä miesten että naisten parissa vitsit seksiskandaaleista ja seksuaalisesta häirinnästä (Boosler, 1993; Franken, 1996; Leno, 2000), abortista ja ehkäisystä (Meyers, 2011; Strong, 2015; Wolf, 2018), naisten roolista politiikassa (Carey, 2002; Ferguson, 2008; Hammond, 2001; Wolf, 2018) ja poliittisen journalismin seksismistä (O’Brien, 1995; Strong, 2015) ovat olleet suosittuja.

Lisäksi omaksi alalajikseen on noussut roastattavien poliittisten toimijoiden ulkonäön pilk- 
kaaminen. Rossingin (2017) mukaan taipumus nauraa poliitikkojen ulkomuodolle, ei niinkään heidän politiikalleen, pitää vitsit yksinkertaisina ja ilman todellista poliittisista sisältöä. Ulkonäkövitsit ovat helppoja tehdä ja helppo ymmärtää. Vuosien varrella illalliset ovat löytäneet suosikkikohteitaan ja ulkonäkökritiikin kohteeksi ovat joutuneet erityisesti entisen ensimmäisen naisen ja presidenttiehdokkaan Hillary Clintonin hiustyylit, entisen kuvernöörin Chris Christien ylipaino ja nykyisen presidentin Donald Trumpin ulkomuoto. Erityisesti Chris Christien kommentointi on muodostunut jo sukupuolirajoja ylittäväksi perinteeksi.

Määrällisesti ulkonäkövitsit ovat kohdistuneet miehiin johtuen pitkälti siitä, että useat poliittiset toimijat niin hallinnon kuin mediankin puolella ovat olleet miehiä. Vitsit miesten ulkonäöstä ovat olleet usein hyvinkin suorasukaisia. Muun muassa Hasan Minhaj (2017) kommentoi, että hän ymmärtää miksei Donald Trump saapunut paikalle roastattavaksi, koska hänen ulkonäöstään huomaa, että hän on paahtunut ("has been roasting") viimeiset 70 vuotta. Kommentti viittaa paitsi Trumpin ikään, myös hänen oranssina pidettyyn ihoonsa. Vastaavasti Cecily Strong (2015) toteaa, että Washingtonissa on hyvän näköisiä (miespuolisia) kongressiedustajia. Hän näkee yleisössäkin monta kympin arvoista, tai Washingtonissa kymppeinä pidettyjä New Yorkin nelosia.

Sen sijaan ulkonäkövitsien kohdistuessa naisiin asetelma muuttuu hieman. Vuosien varrella naisista kritiikkiä ovat kohdanneet erityisesti Hillary Clinton, Michelle Obama, Nancy Pelosi, Sarah Palin, Condoleezza Rice ja Ivanka Trump. Mieskoomikot ovat varovaisia kohdistaessaan naisten ulkonäköön liittyvää kritiikkiä. Muun muassa Darrell Hammond (2001) vitsaili Hillary Clintonista, että tämän silmät eivät hymyile, mutta ei vie vitsiä pidemmälle. Toinen vaihtoehto on liittää ulkonäkötematiikkaan positiivista palautetta. Esimerkiksi Michelle Obaman terveysvalistuskampanjan kohdalla Jimmy Kimmel (2012) teki ulkonäköpaineista vitsejä, mutta liitti ne pikemminkin terveystavoitteisiin kuin ulkonäön pilkkaamiseen.

Tiukin kritiikki naistoimijoille nousi naiskoomikoilta. Wanda Sykes (2009) pilaili poissaolevasta kuvernööri Sarah Palinista, ettei viime hetkellä vetäytyminen ole oikeaa pidättäytymisen harjoittamista ("She pulled out at the last minute. You know, somebody should tell her, that's not how you purely practice abstinence."). Suorasukainen kriittisyys näkyi myös Michelle Wolfin (2018) vitsien kohdalla. Hän vitsaili muun muassa omasta, Chris Christien ja Mitch McConnellin ulkonäöstä.. Nämä saivat yleisön hyväksynnän, sillä miespoliitikkojen ulkonäölle nauraminen ja koomikoiden itseensä kohdistuva huumori ovat totuttuja vitsien muotoja (Gilbert, 2004; Rossing, 2017). Sen sijaan Wolfin aiheuttaman kohun ytimessä oli hänen kritiikkinsä presidentti Trumpin hallinnossa toimiville naisille (Hakola, 2019). Hän kutsui muun muassa Ivanka Trumpia, Kellyann Conwayta ja Sarah Huckabee Sandersia pettymykseksi muille valkoisille naisille. Sandersin kohdalla Wolf hyödynsi myös ulkonäkökritiikkiä. Hän vitsaili Sandersin polttavan faktoja ja käyttävän tuhkan muotoillakseen täydellisen silmämeikin.

Paikalla olevan yleisön reagointi oli moninaista. Vitsit herättivät jonkin verran naurua ja yksittäisiä taputuksia, mutta suurimmaksi osaksi yleisö hiljeni. Lisäksi kamera poimi mukaan yleisökuvia, joissa ihmiset istuvat joko vaisusti hymyillen tai paheksuvan näköisinä. Kamera haki myös reaktiot Conwaylta ja Sandersilta, jotka molemmat pysyivät vakavina. Sandersilla oli lisäksi vaikea pitää yllä neutraalia ilmettä ja hän joutui välillä laskemaan katseensa kootakseen itsensä. Paikan päällä olevalle yleisölle vit- 
sien kohteena olevat eivät helpottaneet tilannetta hyväksymällä vitsit, mutta myöskään Wolf ei tasoittanut vuorovaikutustilannetta. Hän ohitti yleisön reaktiot ja jatkoi eteenpäin monologissaan tehden selväksi, että vitsit ovat ensisijaisesti tarkoitettu kotiyleisöille valtaa horjuttavina käytänteinä. Wolfin aiheuttama kohu kärjistyikin kysymyksiin, olivatko naiskoomikon vitsit liian aggressiivisia ja hyökkäsikö hän liian vahvasti muiden naisten kimppuun.

\section{Kuka saa olla aggressiivinen?}

Kirjeenvaihtajien illallisilla aggressiivisuutta on arvioitu suhteessa siihen, miten vitsin kohde ottaa kritiikin vastaan ja miten koomikko esittää asiansa. Viestin aggressiivisuus syntyy paitsi siitä, miten koomikko ohittaa välittömän yleisöpalautteen, myös muista esiintymistyyliin liittyvistä seikoista. Stephen Colbert (2006) muun muassa oli vakava ja hänen äänensävynsä vaihteli syyttävästä saarnaavaan. Hän korosti sanomaansa käsieleillä, kuten osoittamalla ja heristämällä sormea, osoittelemalla presidentti Bushia ja elehtimällä kuin olisi antamassa oppituntia. Samoin Wolfin (2018) tyyli oli aggressiivinen. Hän puhui nopeasti kovalla äänellä, ja vaikka hän pehmensi olemustaan hymyilemällä, hän osoitti, ettei ole kiinnostunut paikalla olevan yleisön kritiikistä. Vaikka hän alussa totesi olevansa paikalla viihdyttäänä, hän kommentoi seksuaalissävytteisen vitsinsä jälkeen, että järjestäjien olisi tullut tehdä enemmän taustatyötä ennen hänen kutsumistaan. Lisäksi aborttivitsin jälkeen Wolf huomautti, että voitte aivan rauhassa huokailla niin syvään kuin haluatte. Toisin kuin monet muut koomikot hän ei myöskään lopettanut esitystään tunnelmaa kohottavaan "me amerikkalaiset" -tyyliseen kannustuspuheeseen, vaan toteaa poliittisesti, että kuten monen siirtolaistaustaisen lapsen tavoin hänenkin "gotta get the fuck out of here".
Erityisesti Wolfin ja Colbertin komediamonologit ovat olleet kiisteltyjä niiden aggressiivisen tyylin takia (Dodds \& Kirby, 2013; Hakola, 2019). Tosin vain Wolfin esiintyminen aiheutti gaalan komediaperinteen mielekkyyden kyseenalaistamisen. Koska molempina aikakausina aggressiivinen (poliittinen) huumori on ollut merkittävä osa komediakenttää, eroa on mahdollista etsiä sukupuolesta. Politiikka ja poliittinen komedia on molemmat nähty miehisenä tilana niiden aggressiivisen ja valta-asetelmiin perustuvan luonteen takia. Komediatutkijoiden mukaan riehakkuus tai voimakas kielenkäyttö onkin saatettu tulkita miehiseksi etuoikeudeksi ja naisten on odotettu välttävän riidanhaluista tai liian suorasukaista tyyliä komediassaan (Graban, 2014; Mizejewski, 2014; Shouse \& Oppliger, 2012). Heitä on syytetty epänaisellisuudesta, maskuliinisuudesta, ei-hauskuudesta tai epäsopivuudesta käyttäessään aggressiivista tyyliä ja nämä syytökset toistuivat myös Wolfin kohdalla. Näitä sukupuolittuneita oletuksia on haastettu (nais)koomikoiden toimesta ja sukupuolenjälkeistä potentiaalia on usein etsitty tavoista, joilla on tarkoituksellisesti rikottu sukupuolittuneita oletuksia ja tunkeuduttu miehisiksi ymmärrettyihin tiloihin (Foy, 2015). Kyse onkin sen kulttuurisen oletuksen haastamisesta, että aggressiivinen huumori olisi jotenkin lähtökohtaisesti miehistä.

On kuitenkin huomioitava, että mikäli sukupuolenjälkeinen komedia pyrkii siihen, ettei aggressiivista huumoria pidettäisi sukupuolisidonnaisena, tulisi saman käytänteen sisältää myös muut tyylivalinnat. Mikäli naiskoomikko valitsee ei-hyökkäävän tyylin, ei sitä pitäisi tulkita perinteiseksi asetelmaksi, tai mikäli mieskoomikko käyttää lempeitä kritiikin muotoja, ei sitä pitäisi pitää miehelle poikkeavana käytöksenä. 
Nämä esimerkit osoittavat, että illallisilla esiintyneiden koomikoiden väliset tyylierot juontuvat heidän valinnoistaan, ei sinällään heidän sukupuolestaan. Sukupuoli on pikemminkin yksi lisämahdollisuus poliittisen satiirin esittämiseen niin esiintyjän identiteetin kuin vitsien sisällön kautta. Sukupuolenjälkeinen komedia voisi parhaimmillaan laajentaa poliittisen komedian muotoja sisällyttämällä siihen monia erilaisia komediatyylejä ilman niihin liittyvää sukupuolittunutta oletusta.

Kirjeenvaihtajien illallisten formaatti on pysynyt samana koko 25 vuoden ajanjakson. Vuorovaikutustilanteena gaala on poikkeuksellinen, sillä läsnä olevat poliittiset toimijat ovat harvoin koomikkojen ensisijainen yleisö, jota he pyrkisivät naurattamaan. Televisioinnin myötä tilaisuus on korostanut eroja suhteessa siihen, keiden oletetaan tunnistavan vitsien toimivuus. Kirjeenvaihtajien illalliset myös ohjaavat omilla perinteillään aiheita, joista koomikot ammentavat, mikä ei anna täyttä kuvaa poliittisen komedian eri ulottuvuuksista.

Kirjeenvaihtajien illallisten komediamonologit antavat viitteitä siitä, että sukupuolella on edelleen merkittävä rooli poliittisessa komediassa, jossa se on osa esittäjänsä lavapersoonaa ja voi toimia innoittajana komedialliselle poliittis-yhteiskunnalliselle kritiikille. Gaalassa sukupuolitematiikka on pikemminkin ollut kasvussa kuin menossa ohitse, joten tässä valossa sukupuolettomuudesta keskustelu ei vaikuta mielekkäältä. Tästä huolimatta sukupuolenjälkeisyydellä on oma antinsa keskusteltaessa poliittisen komedian tulevaisuudesta. Tässä keskustelussa sukupuolenjälkeisyys kiinnittyy erilaisten sukupuoleen liittyvien hierarkkisten asetelmien purkamiseen. Strategiana kohti sukupuolenjälkeistä komediaa on toiminut olemassa olevien kulttuuristen normien ja odotusten rikkominen, erityisesti hyökkäävää tyyliä suosivien naiskoomikoiden toimesta. Heidän tyylivalintansa ovat osoittaneet, ettei hyökkäävä poliittinen komedia ole lähtökohtaisesti miehinen viestinnän muoto. Kulttuurinen muutos on kuitenkin hidasta ja erityisesti sukupuolittuneet kohut osoittavat yhtäältä sukupuolittuneiden asenteiden olemassaoloa ja toisaalta mahdollistavat näistä asenteista keskustelun.

\section{Kirjallisuus}

Boosler, E. (1.5.1993). 1993 White House Correspondents' Association Dinner [Video]. C-SPAN. https:// www.c-span.org/video/?40370-1/1993-white-house-correspondents-dinner

Brock, A. (2015). Participation frameworks and participation in televised sitcom, candid camera and stand-up comedy. Teoksessa M. Dynel, \& J. Chovanec (toim), Participation in public and social media interactions (s. 27-48). Amsterdam, Philadelphia: John Benjamins Publishing Company.

Brodie, I. (2008). Stand-up comedy as a genre of intimacy. Ethnologies, 30(2), 153-180. https://doi. org/10.7202/019950ar

Butler, J. (1990). Gender trouble: Feminism and the subversion of identity. New York: Routledge.

Carey, D. (4.5.2002). 2002 White House Correspondents' Association Dinner [Video]. C-SPAN. https://www.c-span.org/video/? 169842-1/2002-white-house-correspondents-dinner

Cedric the Entertainer (30.4.2005). 2005 White House Correspondents' Association dinner [Video]. C-SPAN. https://www.c-span.org/ video/? 186439-1/2005-white-house-correspondents-dinner

Colbert, S. (29.4.2006). 2006 White House Correspondents' Association Dinner [Video]. C-SPAN. https://www.c-span.org/video/? 192243-1/2006-white-house-correspondents-dinner 
Colletta, L. (2014). Postmodernity and the gendered uses of political satire. Teoksessa D. Solomon, S. Zwagerman, P. M. St. Pierre, P. Dickinson, \& A. Higgins (toim), Women and comedy: History, theory, practice (s. 207-218). Madison: Fairleigh Dickinson University Press.

Cramer Brownell, K. (2016). The historical presidency Gerald Ford, Saturday Night Live, and the development of the entertainer in chief. Presidential Studies Quarterly, 46(4), 925-942. https:// doi.org/10.1111/psq.12326

Deutscher, P. (1997). Yielding gender: Feminism, deconstruction and the history of philosophy. London \& New York: Routledge.

Dodds, K., \& Kirby, P. (2013). It's not a laughing matter: critical geopolitics, humour and unlaughter. Geopolitics, 18(1), 45-59. https://doi.org/10.1080/14 650045.2012.668723

Double, O. (2014). Getting the joke: The inner workings of stand-up comedy. London \& New York: Bloomsbury.

Ferguson, C. (26.4.2008). 2008 White House Correspondents' Association Dinner [Video]. C-SPAN. https://www.c-span.org/video/?205066-2/2008-white-house-correspondents-dinner

Foy, J. (2015). Fooling around: Female stand-ups and sexual joking. The Journal of Popular Culture, 48(4), 703-713. https://doi.org/10.1111/jpcu.12222

Franken, A. (23.4.1994). 1994 White House Correspondents' Association Dinner [Video]. C-SPAN. https://www.c-span.org/video/?56320-1/1994-white-house-correspondents-dinner

Franken, A. (4.5.1996). 1996 White House Correspondents' Association Dinner [Video]. C-SPAN. https://www.c-span.org/video/?71604-1/1996-white-house-correspondents-dinner

Gilbert, J. R. (2004). Performing marginality: Humor, gender, and cultural critique. Detroit: Wayne State University Press.

Graban, T. S. (2014). Humoring the female pol: Irony, consciousness-raising, and "third-culture" discourse. Teoksessa D. Solomon, S. Zwagerman, P. M. St. Pierre, P. Dickinson, \& A. Higgins (toim), Women and comedy: History, theory, practice (s. 157-170). Madison: Fairleigh Dickinson University Press.
Hakola, O. (2019). Post-gender comedy at the White House Correspondents' Dinner. Teoksessa C. P. Martins (toim), Comedy for dinner and other dishes (s. 43-62). Coimbra: IEF Instituto de Estudos Filosóficos. http://www.uc.pt/fluc/uidief/ebooks/ Comedy_for_dinner

Hammond, D. (28.4.2001). 2001 White House Correspondents' Association Dinner [Video]. C-SPAN. https://www.c-span.org/video/?163957-1/2001-white-house-correspondents-dinner

Haraway, D. (1991). A cyborg manifesto: Science, technology, and socialist-feminism in the late twentieth century. Teoksessa D. Haraway (toim.), Simians, cyborgs and women: The reinvention of nature (s. 149-181). New York: Routledge.

Higgie, R. (2017). Public engagement, propaganda, or both? Attitudes toward politicians on political satire and comedy programs. International Journal of Communication, 11, 930-948. https://ijoc.org/index. php/ijoc/article/view/5675

Joseph, R. L. (2009). "Tyra Banks is fat": Reading (post-)racism and (post-)feminism in the new millennium. Critical Studies in Media Communication, 26(3), 237-254. https://doi. org/10.1080/15295030903015096

Kahn, M. (27.4.2015). An oral history of the White House Correspondents' dinner by the (few) women who've owned it. Elle. https://www.elle.com/culture/ career-politics/a28033/an-oral-history-of-the-white-house-correspondents-dinner-by-the-womenwhove-owned-it/

Kimmel, J. (28.4.2012). 2012 White House Correspondents' Association Dinner [Video]. C-SPAN. https:// www.c-span.org/video/?408834-1/white-house-correspondents-dinner-comedians

Leno, J. (29.4.2000). 2000 White House Correspondents' Association Dinner [Video]. C-SPAN. https:// www.c-span.org/video/?156877-1/2000-whitehouse-correspondents-dinner

Leno, J. (1.5.2004). 2004 White House Correspondents' Association Dinner [Video]. C-SPAN. https:// www.c-span.org/video/?181634-1/2004-white-house-correspondents-dinner

Leno, J. (1.5.2010). 2010 White House Correspondents' Association Dinner [Video]. C-SPAN. https:// www.c-span.org/video/?293275-1/2010-white-house-correspondents-dinner

Lindfors, A. (2019). Cultivating participation and the varieties of reflexivity in stand-up comedy. Journal of Linguistic Anthropology. https://doi.org/10.1111/ jola.12223 
Little, R. (21.4.2007). 2007 White House Correspondents' Association Dinner [Video]. C-SPAN. https:// www.c-span.org/video/?197644-1/2007-white-house-correspondents-dinner

McHale, J. (3.5.2014). 2014 White House Correspondents' Association Dinner [Video]. C-SPAN. https:// www.c-span.org/video/?318916-1/white-house-correspondents-dinner

Meyers, S. (30.4.2011). 2011 White House Correspondents' Association Dinner [Video]. C-SPAN. https:// www.c-span.org/video/?299256-1/2011-white-house-correspondents-dinner

Minhaj, H. (29.4.2017). 2017 White House Correspondents' Association Dinner [Video]. C-SPAN. https://www.c-span.org/video/?426363-1/hasan-minhaj-headlines-white-house-correspondents-association-dinner

Mizejewski, L. (2014). Pretty/Funny: Women comedians and body politics. Austin: University of Texas Press.

Nicholas, L. (2014). Queer post-gender ethics: The shape of selves to come. New York: Palgrave MacMillan.

O’Brien, C. (29.4.1995). 1995 White House Correspondents' Association Dinner [Video]. C-SPAN. https://www.c-span.org/video/?312088-1/2013-white-house-correspondents-dinner

O'Brien, C. (27.4.2013). 2013 White House Correspondents' Association Dinner [Video]. C-SPAN. https://www.c-span.org/video/?312088-1/2013-white-house-correspondents-dinner

Ritchie, C. (2014). "Taking the piss": Mockery as a form of comic communication. Comedy Studies, 5(1), 33-40. https://doi.org/10.1080/2040610X.2014.918809

Romano, R. (25.4.1998). 1998 White House Correspondents' Association Dinner [Video]. C-SPAN. https://www.c-span.org/video/?104055-1/1998-white-house-correspondents-dinner

Rossing, J. P. (2017). Live from DC, it's "nerd prom". Political humor at the white house correspondents' association dinner. Teoksessa M. R. Meier, \& C. R. Schmitt (toim.), Stand-Up comedy and the rhetoric of social change (s. 168-184). New York \& London: Routledge.

Sherine, A. (25.8.2016). The reason why women aren't often funny. The Spectator. https://blogs. spectator.co.uk/2016/08/reason-women-arent-often-funny/
Shouse, E. \& Oppliger, P. (2012). Sarah is magic: The (post-gendered?) comedy of Sarah Silverman. Comedy Studies, 3(2), 201-216. https://doi. org/10.1386/cost.3.2.201_1

Stewart, J. (26.4.1997). 1997 White House Correspondents' Association Dinner [Video]. C-SPAN. https:// www.c-span.org/video/?80690-1/1997-white-house-correspondents-dinner

Strong, C. (25.4.2015). 2015 White House Correspondents' Association Dinner [Video]. C-SPAN. https:// www.c-span.org/video/?325411-2/2015-white-house-correspondents-association-dinner

Sykes, W. (9.5.2009). 2009 White House Correspondents'Association Dinner [Video]. C-SPAN. https:// www.c-span.org/video/?286242-2/2009-white-house-correspondents-dinner

Wilmore, L. (30.4.2016). 2016 White House Correspondents' Association Dinner [Video]. C-SPAN. https://www.c-span.org/video/?407237-103/2016-w hite-house-correspondents-dinner

Wolf, M. (28.4.2018). 2018 White House Correspondents' Association Dinner [Video C-SPAN. https:// www.c-span.org/video/?444555-1/comedian-michelle-wolf-headlines-white-house-correspondents-dinner 